\title{
CHARACTERIZATION OF MOLLUSCICIDAL COMPONENT OF Moringa oleifera LEAF AND Momordica charantia FRUITS AND THEIR MODES OF ACTION IN SNAIL Lymnaea acuminata
}

Aparna UPADHYAY, Vinay K. SINGH \& Dinesh K. SINGH

\begin{abstract}
SUMMARY
The molluscicidal activity of the leaf powder of Moringa oleifera and lyophilized fruit powder of Momordica charantia against the snail Lymnaea acuminata was time and concentration dependent. M. oleifera leaf powder ( $\left.96 \mathrm{~h} \mathrm{LC}_{50}: 197.59 \mathrm{ppm}\right)$ was more toxic than $M$. charantia lyophilized fruit powder $\left(96 \mathrm{~h} \mathrm{LC}_{50}: 318.29 \mathrm{ppm}\right)$. The ethanolic extracts of $M$. oleifera leaf powder and Momordica charantia lyophilized fruit powder were more toxic than other organic solvent extracts. The $96 \mathrm{~h} \mathrm{LC} \mathrm{L}_{50}$ of the column purified fraction of M. oleifera leaf powder was $22.52 \mathrm{ppm}$, while that of $M$. charantia lyophilized fruit powder was $6.21 \mathrm{ppm}$. Column, thin layer and high performance liquid chromatography analysis show that the active molluscicidal components in $M$. oleifera leaf powder and lyophilized fruit of $M$. charantia are benzylamine $\left(96 \mathrm{~h} \mathrm{LC}_{50}: 2.3 \mathrm{ppm}\right)$ and momordicine $\left(96 \mathrm{~h} \mathrm{LC}_{50}: 1.2 \mathrm{ppm}\right)$, respectively. Benzylamine and momordicine significantly inhibited, in vivo and in vitro, the acetylcholinesterase (AChE), acid and alkaline phosphatase (ACP/ALP) activities in the nervous tissues of $L$. acuminata. Inhibition of AChE, ACP and ALP activity in the nervous tissues of $L$. acuminata by benzylamine and momordicine may be responsible for the molluscicidal activity of $M$. oleifera and $M$. charantia fruits, respectively.
\end{abstract}

KEYWORDS: Acetylcholinesterase; Lymnaea acuminata; Momordica charantia; Moringa oleifera; Phosphatases.

\section{INTRODUCTION}

Fascioliasis caused by Fasciola species is of considerable medical and veterinarian importance ${ }^{20,26}$. It severely affects breeding in cattle, goats, horses, ovines and swine, resulting in serious losses which ultimately affect the economy of live-stock keepers in many countries ${ }^{12,19}$. The control of the snail population with the help of molluscicide is one of the major tools to reduce the incidence of fascioliasis in cattle as well as in human beings ${ }^{20,26}$. The development of plant molluscicides, as possible substitutes for synthetic molluscicides, is gaining more attention because they are effective, less expensive and eco-friendly ${ }^{18}$. Many plant products have been found to have a high molluscicidal potential $1^{25,31,34,36}$.

In the present study, the molluscicidal activities of the leaf powder of Moringa oleifera Lam. (Moringaceae) and lyophilized fruit powder of Momordica charantia Linn. (Cucurbitaceae) against the target snail Lymnaea acuminata were evaluated. Active molluscicidal components responsible for snail death were isolated, characterized and their effects on acetylcholinesterase (AChE) and acid / alkaline phosphatase (ACP/ ALP) activity in the nervous tissue of L. acuminata were evaluated.

\section{MATERIALS AND METHODS}

One afternoon in Gorakhpur (Latitude $26^{\circ} 46^{\prime} \mathrm{N}$, Longitude $83^{\circ}$
22' E), U.P. India, fresh $M$. oleifera leaves from the University campus and fresh $M$. charantia fruits from the local agricultural fields were obtained. The specimens of $M$. oleifera leaf (voucher specimen number M-5132) and $M$. charantia fruit (voucher specimen number M-3431) were identified and authenticated by Prof. R.P. Shukla, Taxonomist, Department of Botany, DDU Gorakhpur University, Gorakhpur, U.P. India.

1. Preparation of crude powder: Leaves of $M$. oleifera were dried in an incubator at $37^{\circ} \mathrm{C}$ for $24 \mathrm{~h}$ and then pulverized in an electric grinder (Twister mixer grinder, 410025). The crude powder, thus obtained, was used for the toxicity experiments. The fresh paste of $M$. charantia was obtained by grinding small pieces of fruit with water. This aqueous paste was lyophilized at $-40{ }^{\circ} \mathrm{C}$. The lyophilized fruit powder was stored in airtight desiccators and used for toxicity experiments.

2. Preparation of organic solvent extracts: Five grams each of crude powder of $M$. oleifera leaf and $M$. charantia fruit were extracted separately with $100 \mathrm{~mL}$ of each solvent viz. chloroform, ether, acetone and ethanol at room temperature for $24 \mathrm{~h}$. Each preparation was filtered separately through sterilized Whatman no. 1 filter paper ${ }^{22}$ and the filtered extracts were subsequently evaporated under vacuum at $24{ }^{\circ} \mathrm{C}$. The residues, thus obtained, were used for the determination of molluscicidal activity. The leaf powder of M. oleifera yielded $230 \mathrm{mg}$ of chloroform 


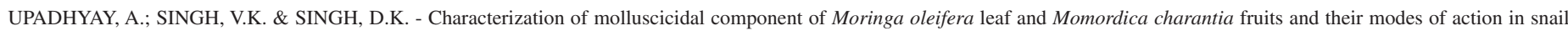
Lymnaea acuminata. Rev. Inst. Med. Trop. Sao Paulo, 55(4): 251-9, 2013.

extract, $355 \mathrm{mg}$ of ether extract, $442 \mathrm{mg}$ of acetone extract and $460 \mathrm{mg}$ of ethanol extract. The lyophilized fruit powder of $M$. charantia yielded $50 \mathrm{mg}$ of chloroform extract, $62 \mathrm{mg}$ of ether extract, $260 \mathrm{mg}$ of acetone extract and $1000 \mathrm{mg}$ of ethanol extract.

3. Column chromatography: Twenty five $\mathrm{mL}$ each of the ethanolic extracts of $M$. oleifera leaf powder and $M$. charantia lyophilized fruit powder were subjected to silica gel (60-120 mesh, Qualigens glass, Precious Electrochemical industry, Pvt. Ltd. Mumbai, India) chromatography in a $5 \mathrm{~cm} \times 45 \mathrm{~cm}$ column. Five $\mathrm{mL}$ fractions of 90 and 60 eluates were eluted with $95 \%$ ethanol for each column preparation of $M$. oleifera leaf powder and lyophilized fruit powder of $M$. charantia, respectively. Eluate nos. 20-30 (M. oleifera leaf powder) and 30-40 (M. charantia lyophilized fruit powder) were used for toxicity studies. Ethanol was evaporated under vacuum at $24{ }^{\circ} \mathrm{C}$ and the residues were used for the determination of molluscicidal activity.

4. Pure compounds: Benzylamine (1-Phenylmethanamine) was purchased from Sigma Chemical Co., USA. and momordicine (3,7,23-trihydroxycucurbita-5,24-dien-19-al) from Yian Khonest BioTech Co. Ltd., China.

5. Thin layer chromatography: Thin layer chromatography (TLC) was performed according to the method of JAISWAL \& $\mathrm{SINGH}^{15}$ to identify the active molluscicidal components in M. oleifera leaf powder and $M$. charantia lyophilized fruit powder. Thin layer chromatography was carried out on $20 \mathrm{~cm} \times 20 \mathrm{~cm}$ precoated silica gel (Precious Electrochemical industry, Pvt. Ltd. Mumbai, India) using benzene/ethyl acetate (9:1, v:v) as the mobile phase. The loading of column purified fractions of $M$. oleifera leaf powder and $M$. charantia lyophilized fruit powder along with their respective active components were applied on TLC plates with a micropipette. TLC plates were developed with $\mathrm{I}_{2}$ vapor. Copies of chromatogram were made by tracing the plates immediately and $\mathrm{Rf}$ values were calculated.

6. High performance liquid chromatography: Identification of active components present in $M$. oleifera leaf and $M$. charantia fruit were done by HPLC.

6.1. Sample preparation: $M$. oleifera leaf and $M$. charantia fruit samples were prepared by dissolving separately $50 \mathrm{mg}$ each of their column chromatographed extracts in $20 \mathrm{~mL}$ of acetonitrile. The samples were properly vortexed to ensure dissolution. Prior to sample injection, the solutions were passed through a Millipore filter (ultra filter disc 3K 43 $\mathrm{mm} 10 \mathrm{pk}$, Cole Parmer, Germany) to remove any undissolved particles.

6.2. Preparation of standard solution: Pure standard solutions of benzylamine $(0.01 \mathrm{M})$ and momordicine $(0.001 \mathrm{M})$ were prepared by diluting $0.01 \mathrm{~mL}$ of benzylamine in $20 \mathrm{~mL}$ of acetonitrile and dissolving $10 \mathrm{mg}$ of momordicine in $20 \mathrm{~mL}$ of acetonitrile. The mixtures were vortexed to ensure proper dissolution of pure compounds. The solutions, thus obtained, were passed through Millipore filter (ultra filter disc $3 \mathrm{~K}$ 43 mm 10 pk, Cole Parmer, Germany).

6.3. Instrumentation: The HPLC system was equipped with two LC10 AT VP pumps, a Cecil CE 4201 UV-variable detector and a Microliter ${ }^{\circledR}$ \#702 (Hamilton-Bonaduz, Schweiz) syringe with a loop size of $20 \mu \mathrm{L}$. Reverse-phase chromatographic analysis was carried out under isocratic conditions using a reverse-phase Luna $5 \mu \mathrm{C}_{18}$ Phenomenex column (250 $\mathrm{mm} \times 4.6 \mathrm{~mm}$ ) at $27{ }^{\circ} \mathrm{C}$. Acetonitrile (HPLC grade) was used as the mobile phase solvent under a pressure of $260-270 \mathrm{Kgf} / \mathrm{cm}^{2}$ and run time of $15 \mathrm{~min}$. The analysis was carried out at a flow rate of one $\mathrm{mL} / \mathrm{min}$., the column effluent being monitored at $260 \mathrm{~nm}$. Data acquisition were done with Power Stream ${ }^{\mathrm{TM}}$ software.

7. Collection of snails: Adult freshwater snails (L. acuminata, 2.25 $\mathrm{cm} \pm 0.20 \mathrm{~cm}$ in shell length) were collected locally from different ponds in Gorakhpur, India. They were acclimatized for $72 \mathrm{~h}$ to laboratory conditions in a glass aquarium containing dechlorinated tap water (Temp., 22-24 ${ }^{\circ} \mathrm{C}$; $\mathrm{pH}, 7.1-7.3$; dissolved oxygen, 6.5-7.2 ppm; free carbon dioxide, 5.2-6.3 ppm; bicarbonate alkalinity, 102-105 ppm).

8. Treatment protocol for concentration-response relationship: The toxicity experiments were performed according to the method of SINGH \& AGARWAL ${ }^{29}$. Ten experimental snails were kept in a glass aquarium containing $3 \mathrm{~L}$ of dechlorinated tap water. Snails were continuously exposed for $96 \mathrm{~h}$ to different concentrations of plant products, separately. Six aquaria were set up for each concentration. Control snails were kept in the equal volumes of dechlorinated tap water under similar conditions without treatment. Snail mortality was assessed at 24 hourly intervals up to $96 \mathrm{~h}$. Dead animals were promptly removed to avoid contamination of aquarium water. Mortality was indicated by the contraction of body within the shell; lack of response to a needle probe was taken as evidence of death. The LC values, lower and upper confidence limits (LCL and UCL), slope values, t-ratio, g-values and heterogeneity factors were calculated using the POLO computer software of ROBERTSON et al. ${ }^{24}$. The regression coefficient between exposure time and different $\mathrm{LC}_{50}$ values was determined by the method of SOKAL \& ROHLF $^{32}$.

9. Bioassays: Each set of experimental snails were exposed to sublethal concentrations; $40 \%$ and $80 \%$ of $24 \mathrm{~h} \mathrm{LC}_{50}$ and $40 \%$ and $80 \%$ of $96 \mathrm{~h} \mathrm{LC}_{50}$ of different molluscicides for 24 and $96 \mathrm{~h}$, respectively. The sublethal concentrations were based on 24 and $96 \mathrm{~h} \mathrm{LC}_{50}$ values obtained from section 8. After 24 and $96 \mathrm{~h}$ of exposure, snails were removed from aquaria and rinsed with water. The nervous tissues of snails in experimental and control groups were taken out for the measurement of acetylcholinesterase (AChE), acid phosphatase (ACP) and alkaline phosphatase (ALP) activities.

The in vitro experiments were performed by dissolving benzylamine $(0.3,0.5,0.7$ and $0.8 \mathrm{mM})$ and momordicine $(0.06,0.11,0.15$ and 0.19 $\mathrm{mM}$ ) in ether, and $4 \mathrm{~mL}$ of each was added separately to $10 \mathrm{~mm}$ path length cuvette. Ether was then allowed to evaporate. Molluscicides were pre-incubated with an enzyme source for $15 \mathrm{~min}$ at $25^{\circ} \mathrm{C}$, following which enzyme activity was determined. The control cuvette contained ether only. The Michaelis-Menten constant $(\mathrm{Km})$ and maximum velocity $\left(\mathrm{V}_{\max }\right)$ were calculated by plotting Lineweaver-Burk plots for the hydrolysis of different concentrations of substrate by treated $(0.7 \mathrm{mM}$ of benzylamine and $0.15 \mathrm{mM}$ of momordicine) and untreated enzyme $\mathrm{e}^{28}$.

\section{Enzyme assay}

10.1. Acetylcholinesterase: Acetylcholinesterase activity was measured according to the method of ELLMAN et al. ${ }^{9}$ as modified by SINGH \& AGARWAL ${ }^{27}$. Fifty milligrams of the nervous tissue of 


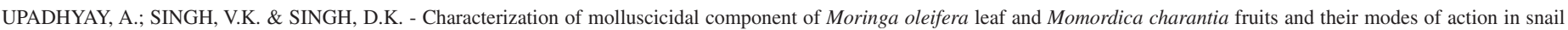
Lymnaea acuminata. Rev. Inst. Med. Trop. Sao Paulo, 55(4): 251-9, 2013.

L. acuminata taken around the buccal mass was homogenized in $1.0 \mathrm{~mL}$ of $0.1 \mathrm{M}$ phosphate buffer $\mathrm{pH} 8.0$ for five min in an ice bath and centrifuged at $1000 \mathrm{~g}$ for $30 \mathrm{~min}$ at $4{ }^{\circ} \mathrm{C}$. The supernatant was used as the enzyme source. Enzyme activity was measured in a $10 \mathrm{~mm}$ path-length cuvette using an incubation mixture consisting of $0.1 \mathrm{~mL}$ of enzyme source, 2.9 $\mathrm{mL}$ of $0.1 \mathrm{M}$ phosphate buffer $\mathrm{pH} 8,0.1 \mathrm{~mL}$ of chromogenic agent DTNB (5,5'-dithio-bis-2-nitrobenzoic acid) and $0.02 \mathrm{~mL}$ of freshly prepared ATChI (acetylthiocholine iodide) solution in distilled water. The change in optical density at $412 \mathrm{~nm}$ was recorded every $30 \mathrm{secs}$ for three min at $25^{\circ} \mathrm{C}$. Enzyme activity was expressed as $\mu \mathrm{mol}$ ' $\mathrm{SH}$ ' hydrolyzed/min/mg protein.

For the estimation of the kinetic constants of $\mathrm{AChE}$, in vitro inhibition of the enzyme was carried out at different concentrations $\left(3.0 \times 10^{-4}, 5.0 \times\right.$ $10^{-4}, 7.0 \times 10^{-4}$ and $\left.1.0 \times 10^{-3} \mathrm{M}\right)$ of the substrate acetylthiocholine iodide.

10.2. Acid and alkaline phosphatase: Acid and alkaline phosphatase activities in the nervous tissue of $L$. acuminata were measured according to the method of BERGMEYER ${ }^{3}$ as modified by SINGH \& AGARWAL ${ }^{30}$ using p-Nitrophenyl phosphate as the substrate. Tissue homogenate ( $2 \%$, $\mathrm{w} / \mathrm{v}$ ) was prepared in ice cold $0.9 \% \mathrm{NaCl}$ and centrifuged at $5000 \mathrm{~g}$ for 15 min at $4{ }^{\circ} \mathrm{C}$. The supernatant was used as the enzyme source. Standard curves were drawn with p-nitrophenol. The yellow color developed due to the formation of p-nitrophenol was determined colorimetrically at $420 \mathrm{~nm}$. Enzyme activities of acid and alkaline phosphatases (ACP/ ALP) were expressed as $\mu \mathrm{mol}$ substrate hydrolyzed $/ 30 \mathrm{~min} / \mathrm{mg}$ protein.

For the determination of the kinetic constants of acid and alkaline phosphatases, in vitro inhibition of the enzymes was carried out at different concentrations $\left(1.25 \times 10^{-5}, 1.8 \times 10^{-5}, 3.0 \times 10^{-5}\right.$ and $5.4 \times 10^{-5}$ $\mathrm{M})$ of the substrate p-nitrophenyl phosphate.

11. Protein: Protein estimation was carried out according to the method of LOWRY et al. ${ }^{17}$ using bovine serum as a standard. $1.0 \mathrm{~mL}$ of enzyme supernatant was mixed in $5.0 \mathrm{~mL}$ of $5 \%$ trichloroacetic acid TCA and centrifuged at $6000 \mathrm{~g}$ for $20 \mathrm{~min}$. The precipitate was washed with $5.0 \mathrm{~mL}$ of $5 \%$ TCA and again centrifuged at the same speed for $20 \mathrm{~min}$. The precipitate was dissolved in $4.0 \mathrm{~mL}$ of $1 \mathrm{~N} \mathrm{NaOH}$. One $\mathrm{mL}$ of dissolved solution was mixed with $5.0 \mathrm{~mL}$ of reagent $\mathrm{C}\{50 \mathrm{~mL}$ of $2 \%$ sodium carbonate in $0.1 \mathrm{~N} \mathrm{NaOH}$ (reagent A) mixed with $1 \mathrm{~mL}$ of copper sulphate in $1 \%$ sodium potassium tartarate (reagent B) $\}$, and the mixture was left standing for $10 \mathrm{~min}$ at room temperature. In the reaction mixture, $0.5 \mathrm{~mL}$ of reagent $\mathrm{D}$ (freshly prepared phenol reagent and distilled water in 1:2 ratio) was added and mixed thoroughly. Resulting blue color was monitored in absorbance at $600 \mathrm{~nm}$ after $10 \mathrm{~min}$. Standard curves were prepared with different concentrations of bovine serum albumin.

12. Statistical analysis: Each experiment was replicated at least six times and the results expressed as mean \pm SE of six replicates. The Student's t-test was used to test for any significant variation $(p<0.05)$ between control and treated groups ${ }^{32}$.

\section{RESULTS}

1. Molluscicidal activity: The toxicity of different extracts of the leaf powder of M. oleifera and lyophilized fruit powder of $M$. charantia were time and concentration dependent. The $24 \mathrm{~h}$ and $96 \mathrm{~h} \mathrm{LC}_{50}$ values of the leaf powder of M. oleifera were $602.75 \mathrm{ppm}$ and $197.6 \mathrm{ppm}$, respectively (Fig. 3) while the corresponding values for lyophilized $M$. charantia fruit powder were 1249.12 and 318.29 ppm, respectively (Fig. 4). Maximum toxicities were recorded with the ethanolic extracts (Fig. 3-4). The columnpurified fractions of $M$. oleifera and $M$. charantia were highly toxic. The $24 \mathrm{~h}$ and $96 \mathrm{~h} \mathrm{LC}_{50}$ values of the column- purified fraction of M. oleifera leaf powder were 53.16 and $22.52 \mathrm{ppm}$, respectively while those of the column-purified fraction of lyophilized fruit powder of $M$. charantia were 12.33 and $6.21 \mathrm{ppm}$, respectively. The $24 \mathrm{~h} \mathrm{LC}_{50}$ values of benzylamine and momordicine were 14.4 and 10.0 ppm, respectively (Fig. 5-6).

The slope values were steep and separate estimation of LC, based on each of the six replicates, were found to be within $95 \%$ confidence limits of $\mathrm{LC}_{50}$. The t-ratio was higher than 1.96 and heterogeneity factor was less than 1.0. The g-value was less than 0.5 at all the probability levels i.e. 90, 95, 99. There was significant negative regression $(p<0.05)$ between exposure time and $\mathrm{LC}_{50}$ values (Fig. 1-2).

The thin layer chromatography analysis showed that the Rf values of benzylamine (0.06) and momordicine $(0.13)$ were equivalent to the Rf values of column-purified fractions of $M$. oleifera $(0.06)$ and $M$. charantia (0.13).

Identification of active components was done by comparing the retention time (Rt) and chromatographic peaks of $M$. oleifera leaf and $M$. charantia fruit samples with their respective active components,

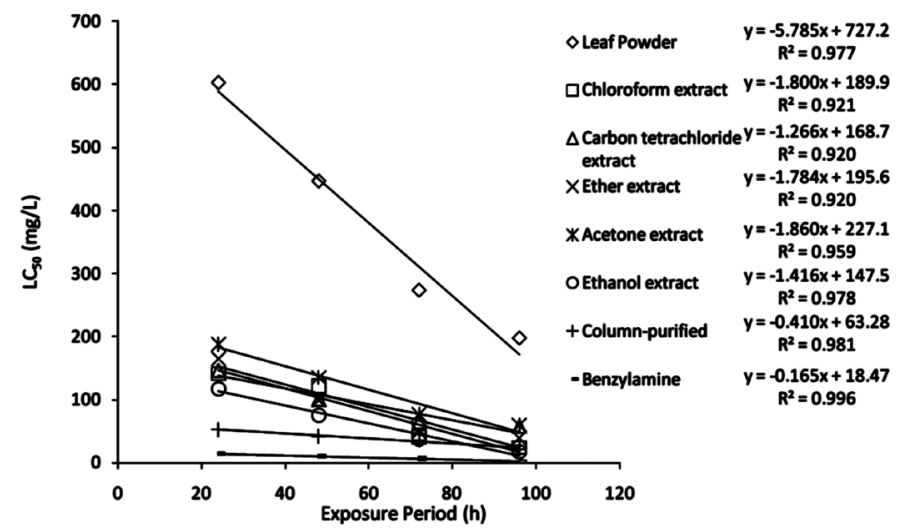

Fig. 1 - Regression analysis in between $\mathrm{LC}_{50}$ of different preparations of Moringa oleifera and exposure time.

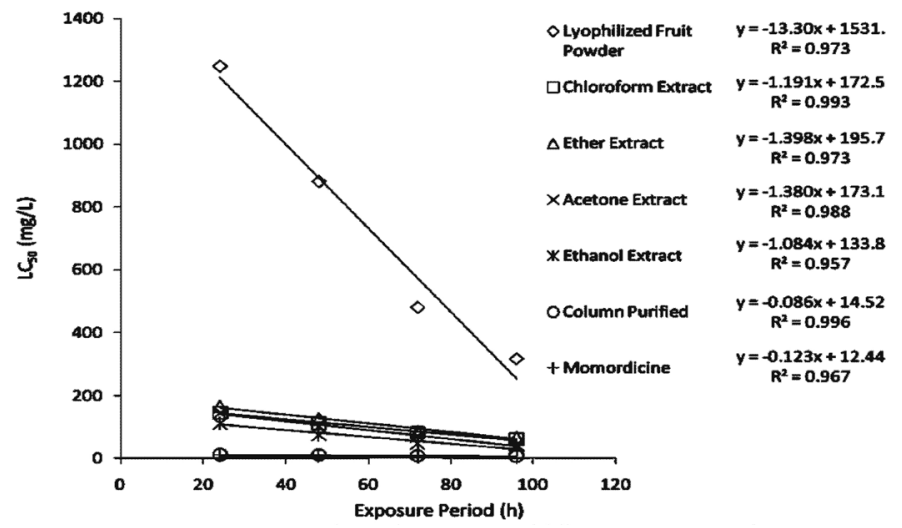

Fig. 2 - Regression analysis in between $\mathrm{LC}_{50}$ of different preparations of Momordica chaiarant and exposure time. 
UPADHYAY, A.; SINGH, V.K. \& SINGH, D.K. - Characterization of molluscicidal component of Moringa oleifera leaf and Momordica charantia fruits and their modes of action in snail Lymnaea acuminata. Rev. Inst. Med. Trop. Sao Paulo, 55(4): 251-9, 2013.

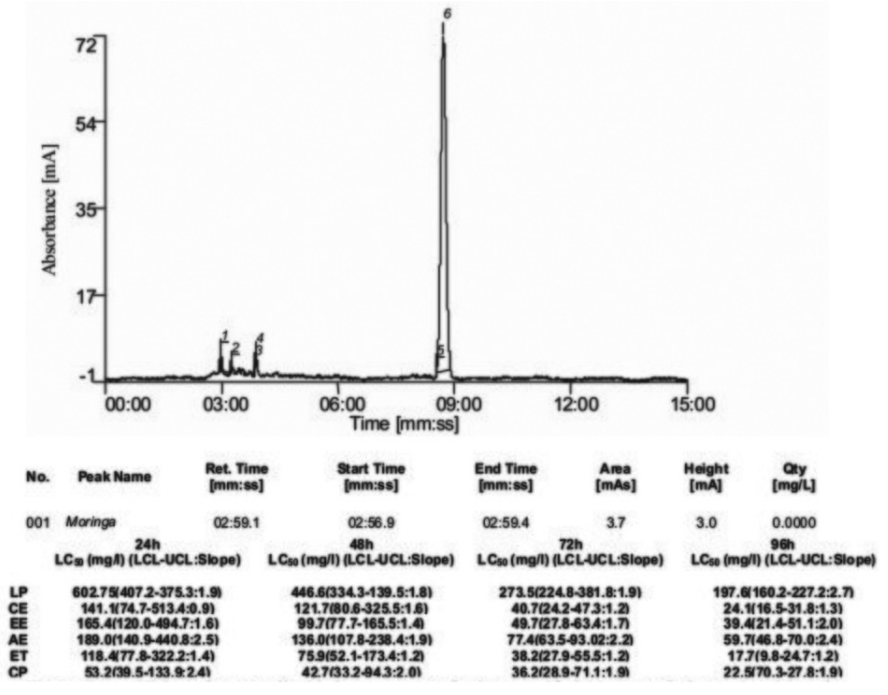

Fig. 3 - High performance liquid chromatogram of column purified Moringa oleifera and toxicity of their different preparations viz. Leaf powder (LP), Chloroform extract (CE), Ether extract (EE), Acetone extract (AE), Ethanol extract (ET) and Column purified extract (CP) against the snail Lymnaea acuminata at different exposure period. LCL (Lower confidence limit), UCL (Upper confidence limit).

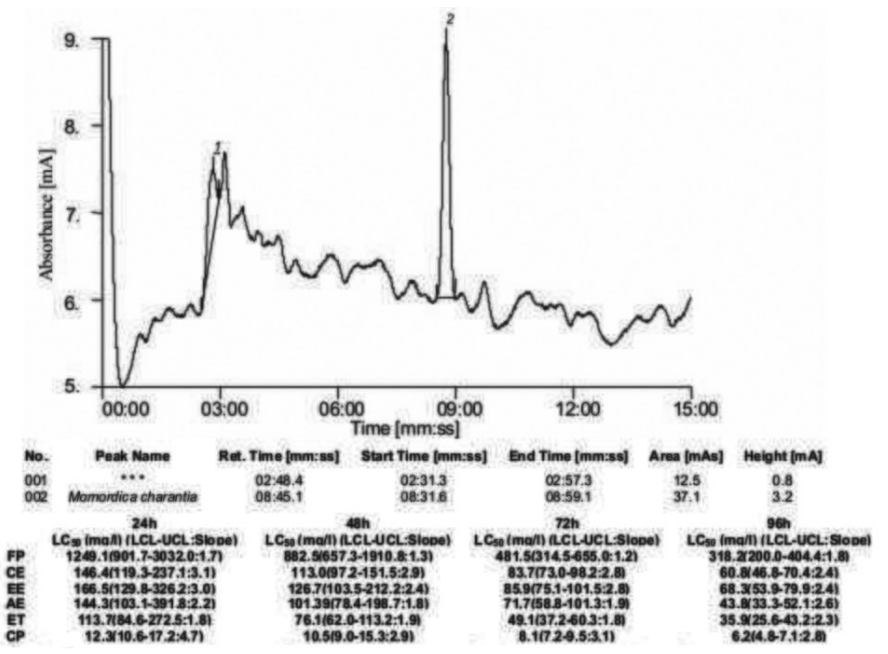

Fig. 4 - High performance liquid chromatogram of column purified Momordica charantia and toxicity of their different preparations viz. Fruit powder (FP), Chloroform extract (CE), Ether extract (EE), Acetone extract (AE), Ethanol extract (ET) and Column purified extract (CP) against the snail Lymnaea acuminata at different exposure period. LCL (Lower confidence limit), UCL (Upper confidence limit).

benzylamine and momordicine (Fig. 3-6). The HPLC fingerprint profiles of $M$. oleifera leaf and $M$. charantia fruit samples showed major peaks at the retention time of $2.59 \mathrm{~min}$ and $8.45 \mathrm{~min}$, respectively, whereas, the pure standard solutions of benzylamine and momordicine showed major peaks at the retention time of $2.58 \mathrm{~min}$ and $8.49 \mathrm{~min}$, respectively.

\section{In vivo inhibition of enzymes}

2.1. Acetylcholinesterase: Table 1 shows that acetylcholinesterase activity in the nervous tissue of control $L$. acuminata was $0.74 \mu \mathrm{mol}$

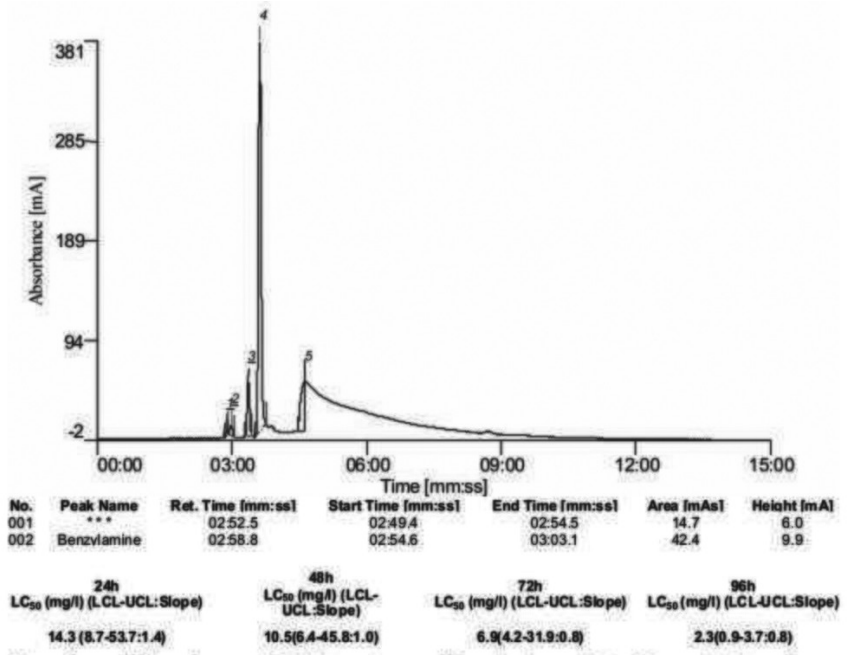

Fig. 5 - High performance liquid chromatogram of Benzylamine and its toxicity against the snail Lymnaea acuminata at different exposure period. LCL (Lower confidence limit), UCL (Upper confidence limit).

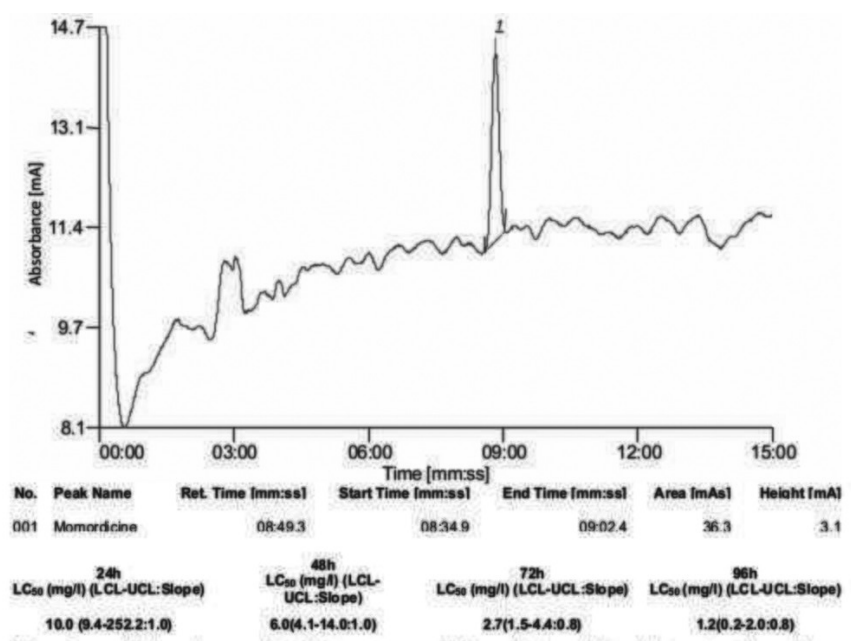

Fig. 6 - High performance liquid chromatogram of Momordicine and its toxicity against the snail Lymnaea acuminata at different exposure period. LCL (Lower confidence limit), UCL (Upper confidence limit).

'SH' hydrolyzed/min/mg protein. In vivo exposure to $40 \%$ and $80 \%$ of 24 and $96 \mathrm{~h} \mathrm{LC}_{50}$ of benzylamine and momordicine caused significant inhibition of AChE activity in the nervous tissue of L. acuminata. AChE activity decreased to $85.27 \%$ and $64.32 \%$ of control values after exposure to $80 \%$ of the $24 \mathrm{~h} \mathrm{LC}_{50}$ of benzylamine and momordicine, respectively. Maximum inhibition of AChE activity was observed when snails were exposed to $80 \%$ of the $96 \mathrm{~h} \mathrm{LC}_{50}$ values of momordicine $(48.91 \%$ of control) and benzylamine (57.02\% of control) (Table 1).

2.2. Acid phosphatase: Acid phosphatase activity in the nervous tissue of control L. acuminata of control group was $35.44 \mu \mathrm{mol}$ substrate hydrolyzed $/ 30 \mathrm{~min} / \mathrm{mg}$ protein (Table 1). In vivo exposure to $40 \%$ and $80 \%$ respectively, of the 24 and $96 \mathrm{~h} \mathrm{LC}_{50}$ values of benzylamine and momordicine caused significant inhibition of ACP activity in the nervous tissue of L. acuminata. ACP activity decreased to $55.30 \%$ and 


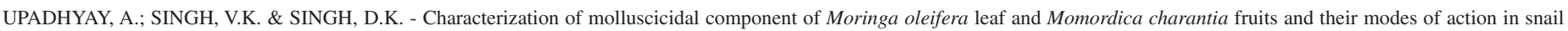
Lymnaea acuminata. Rev. Inst. Med. Trop. Sao Paulo, 55(4): 251-9, 2013.

Table 1

In vivo effect of $24 \mathrm{~h}$ and $96 \mathrm{~h}$ exposure to sublethal concentration of benzylamine and momordicine on acetylcholinesterase (AChE), acid phosphatase (ACP) and alkaline phosphatase (ALP) activity in the nervous tissue of Lymnaea acuminata

\begin{tabular}{|c|c|c|c|c|c|c|}
\hline \multirow{3}{*}{ Enzyme } & \multirow{3}{*}{ treatment } & \multicolumn{5}{|c|}{ Enzyme activity } \\
\hline & & \multirow[b]{2}{*}{ Control } & $24 \mathrm{~h}$ & \multicolumn{3}{|c|}{$96 \mathrm{~h}$} \\
\hline & & & $\begin{array}{c}40 \% \text { of } \mathrm{LC}_{50} \mathrm{~A}(5.74 \\
\mathrm{ppm}) \mathrm{B}(7.61 \mathrm{ppm})\end{array}$ & $\begin{array}{c}80 \% \text { of } \mathrm{LC}_{50} \mathrm{~A}(11.49 \\
\mathrm{ppm}) \mathrm{B}(15.22 \mathrm{ppm})\end{array}$ & $\begin{array}{c}40 \% \text { of } \mathrm{LC}_{50} \mathrm{~A}(0.94 \\
\mathrm{ppm}) \mathrm{B}(0.49 \mathrm{ppm})\end{array}$ & $\begin{array}{c}80 \% \text { of } \mathrm{LC}_{50} \mathrm{~A}(1.89 \\
\mathrm{ppm}) \mathrm{B}(0.98 \mathrm{ppm})\end{array}$ \\
\hline \multirow{2}{*}{$\mathrm{AChE}$} & Benzylamine & $\begin{array}{l}0.74 \pm 0.02 \\
\quad(100)\end{array}$ & $\begin{array}{c}0.64 \pm 0.003 * \\
(86.89)\end{array}$ & $\begin{array}{c}0.63 \pm 0.00 * \\
(85.27)\end{array}$ & $\begin{array}{l}0.54 \pm 0.003 * \\
\quad(73.51)\end{array}$ & $\begin{array}{l}0.42 \pm 0.011 * \\
\quad(57.02)\end{array}$ \\
\hline & Momordicine & $\begin{array}{l}0.74 \pm 0.02 \\
\quad(100)\end{array}$ & $\begin{array}{c}0.53 \pm 0.005 * \\
\quad(71.21)\end{array}$ & $\begin{array}{c}0.48 \pm 0.005 * \\
(64.32)\end{array}$ & $\begin{array}{c}0.40 \pm 0.007 * \\
(54.05)\end{array}$ & $\begin{array}{c}0.36 \pm 0.005^{*} \\
(48.91)\end{array}$ \\
\hline \multirow{2}{*}{$\mathrm{ACP}$} & Benzylamine & $\begin{array}{c}35.44 \pm 0.05 \\
\quad(100) \\
\end{array}$ & $\begin{array}{c}28.56 \pm 0.01 * \\
(80.58) \\
\end{array}$ & $\begin{array}{c}19.60 \pm 0.17 * \\
(55.30)\end{array}$ & $\begin{array}{l}18.12 \pm 0.11 * \\
(51.12)\end{array}$ & $\begin{array}{c}14.44 \pm 0.04 * \\
(40.74)\end{array}$ \\
\hline & Momordicine & $\begin{array}{l}35.44 \pm 0.05 \\
\quad(100)\end{array}$ & $\begin{array}{l}20.68 \pm 0.02 * \\
\quad(58.35)\end{array}$ & $\begin{array}{c}18.97 \pm 0.03 * \\
(53.52)\end{array}$ & $\begin{array}{c}17.88 \pm 0.06^{*} \\
(50.45)\end{array}$ & $\begin{array}{c}15.03 \pm 0.16^{*} \\
(42.40)\end{array}$ \\
\hline \multirow{2}{*}{ ALP } & Benzylamne & $\begin{array}{l}32.44 \pm 0.15 \\
\quad(100)\end{array}$ & $\begin{array}{l}24.05 \pm 0.01 * \\
\quad(74.13)\end{array}$ & $\begin{array}{l}21.51 \pm 0.01 * \\
\quad(75.30)\end{array}$ & $\begin{array}{c}19.55 \pm 0.16^{*} \\
(68.80)\end{array}$ & $\begin{array}{l}17.82 \pm 0.22 * \\
(63.62)\end{array}$ \\
\hline & Momordicine & $\begin{array}{l}32.44 \pm 0.15 \\
\quad(100)\end{array}$ & $\begin{array}{c}21.13 \pm 0.03 * \\
(68.80)\end{array}$ & $\begin{array}{l}18.29 \pm 0.07 * \\
(59.55)\end{array}$ & $\begin{array}{l}17.54 \pm 0.37 * \\
(57.11)\end{array}$ & $\begin{array}{l}16.34 \pm 0.04 * \\
(53.20)\end{array}$ \\
\hline
\end{tabular}

Values are mean \pm SE of six replicates. Values in parentheses indicate percent enzyme activity with control taken as $100 \%$. Concentrations (w/v) have been expressed as final concentration in aquarium water. Acetylcholinesterase activity, $\mu \mathrm{mol}$ ' $\mathrm{SH}$ ' hydrolyzed/min $/ \mathrm{mg}$ protein. Acid phosphatase activity, $\mu \mathrm{mol}$ substrate hydrolyzed/30 $\mathrm{min} / \mathrm{mg}$ protein. Alkaline phosphatase activity, $\mu \mathrm{mol}$ substrate hydrolyzed/30 $\mathrm{min} / \mathrm{mg}$ protein. A, benzylamine; B,momordicine. ${ }^{*}$ Significant $(p<0.05)$ when Student's t-test was used for locating difference between treated and control group of animals.

$53.52 \%$ of control values after exposure to $80 \%$ of the $24 \mathrm{~h} \mathrm{LC}_{50}$ values of benzylamine and momordicine, respectively. Maximum inhibition of ACP activity was observed when snails were exposed to $80 \%$ of the 96 $\mathrm{h} \mathrm{LC}_{50}$ of benzylamine (40.74\% of control) and momordicine $(42.40 \%$ of control) (Table 1).

2.3. Alkaline phosphatase: Alkaline phosphatase activity in the nervous tissue of control L. acuminata was $32.44 \mu \mathrm{mol}$ substrate hydrolyzed $/ 30 \mathrm{~min} / \mathrm{mg}$ protein (Table 1 ). In vivo exposure to $40 \%$ and $80 \%$ respectively of the 24 and $96 \mathrm{~h} \mathrm{LC}_{50}$ values of benzylamine and momordicine caused significant inhibition of ALP activity in the nervous tissue of L. acuminata. ALP activity decreased to $75.30 \%$ and $59.55 \%$ of control values after exposure to $80 \%$ of the $24 \mathrm{~h} \mathrm{LC}_{50}$ values of benzylamine and momordicine, respectively. Maximum inhibition of ALP activity was observed when snails were exposed to $80 \%$ of the $96 \mathrm{~h} \mathrm{LC}_{50}$ values of momordicine (53.20\% of control) and benzylamine (63.62\% of control) (Table 1).

3. In vitro inhibition of enzymes: In vitro pre-incubation with 0.3 , $0.5,0.7$ and $0.8 \mathrm{mM}$ benzylamine and $0.06,0.11,0.15$ and $0.19 \mathrm{mM}$ momordicine caused significant dose dependent inhibition of AChE, ACP and ALP activities (Table 2). In vitro exposure to $0.7 \mathrm{mM}$ of benzylamine and $0.15 \mathrm{mM}$ of momordicine reduced AChE, ACP and ALP activity in the nervous tissue of L. acuminata (Table 2).

Fig. 7 shows Lineweaver-Burk plots of benzylamine and momordicine inhibited and uninhibited AChE activities at different substrate concentrations. This plot shows that the $\mathrm{K}_{\mathrm{m}}$ and $\mathrm{V}_{\text {max }}$ values of uninhibited AChE were $7.69 \times 10^{-4} \mathrm{M}$ and $1.67 \mu \mathrm{mol}$ 'SH' hydrolyzed/ $\mathrm{min} / \mathrm{mg}$ protein, respectively (Table 3 ). $\mathrm{K}_{\mathrm{m}}$ of benzylamine (Fig. 7A) and momordicine (Fig. 7B) inhibited AChE were $10 \times 10^{-4}$ and $2.85 \times 10^{-4}$ $\mathrm{M}$, respectively. $\mathrm{V}_{\max }$ of benzylamine and momordicine-inhibited AChE were 1.67 and $0.48 \mu \mathrm{mol}$ ' $\mathrm{SH}$ ' hydrolyzed $/ \mathrm{min} / \mathrm{mg}$ protein, respectively (Table 3). $\mathrm{K}_{\mathrm{m}}$ and $\mathrm{V}_{\text {max }}$ value of uninhibited ACP were $1.89 \times 10^{-5} \mathrm{M}$ and $58.82 \mu$ mole substrate hydrolyzed $/ 30 \mathrm{~min} / \mathrm{mg}$ protein, respectively. $\mathrm{K}_{\mathrm{m}}$ of benzylamine (Fig. 8A) and momordicine (Fig. 8B) inhibited ACP were $1.40 \times 10^{-5}$ and $1.85 \times 10^{-5} \mathrm{M}$, respectively. $\mathrm{V}_{\max }$ values of benzylamine and momordicine inhibited ACP were 45.45 and $47.61 \mu$ mol substrate hydrolyzed/30 $\mathrm{min} / \mathrm{mg}$ protein, respectively. Fig. 9 shows LineweaverBurk plots of benzylamine and momordicine inhibited and uninhibited ALP activity. $\mathrm{K}_{\mathrm{m}}$ and $\mathrm{V}_{\max }$ value of uninhibited ALP were $2.12 \times 10^{-5} \mathrm{M}$ and $66.67 \mu$ mole substrate hydrolyzed $/ 30 \mathrm{~min} / \mathrm{mg}$ protein, respectively (Table 3). $\mathrm{K}_{\mathrm{m}}$ of benzylamine (Fig. $9 \mathrm{~A}$ ) and momordicine (Fig. $9 \mathrm{~B}$ ) inhibited ALP were $3.22 \times 10^{-5}$ and $2.12 \times 10^{-5} \mathrm{M}$, respectively. $\mathrm{V}_{\max }$ values of benzylamine and momordicine inhibited ALP were 62.50 and 52.63 $\mu$ mole substrate hydrolyzed $/ 30 \mathrm{~min} / \mathrm{mg}$ protein, respectively (Table 3 ).

\section{DISCUSSION}

Results of the present study indicate that the leaf powder of M. oleifera and lyophilized fruit powder of $M$. charantia are potential molluscicides of plant origin. Their toxicities are time and concentration dependent, as evidenced in the negative regression between exposure period and $\mathrm{LC}_{50}$ values of the different treatments. The time-dependent toxic effects of tested plant products may be due to the uptake of active components by snails, which progressively increases in the body with an increase in exposure duration. It is also possible that the active compound(s) could change into more toxic forms in the aquarium water or in the snail's body due to the action of various enzymes. The higher toxicities of ethanolic extracts of $M$. oleifera leaf powder and $M$. charantia lyophilized fruit 


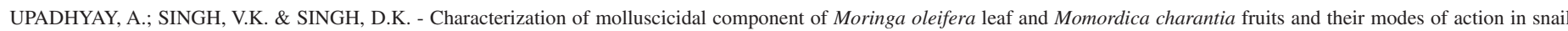
Lymnaea acuminata. Rev. Inst. Med. Trop. Sao Paulo, 55(4): 251-9, 2013.

Table 2

In vitro effect of different concentrations $(\mathrm{mM})$ of benzylamine and momordicine on the acetylcholinesterase (AChE), acid phosphatase (ACP) and alkaline phosphatase (ALP) activity in the nervous tissue of Lymnaea acuminata

\begin{tabular}{|c|c|c|c|c|c|c|}
\hline Enzyme & Treatment & & & Enzyme activity & & \\
\hline \multirow{2}{*}{$\mathrm{AChE}$} & Benzylamine & $\begin{array}{c}\text { Control } \\
0.73 \pm 0.02 \\
(100)\end{array}$ & $\begin{array}{c}0.3 \mathrm{mM} \\
0.65 \pm 0.01 * \\
(88.35)\end{array}$ & $\begin{array}{c}0.5 \mathrm{mM} \\
0.57 \pm 0.007 * \\
(79.17)\end{array}$ & $\begin{array}{c}0.7 \mathrm{mM} \\
0.54 \pm 0.003 * \\
(73.97)\end{array}$ & $\begin{array}{c}0.8 \mathrm{mM} \\
0.43 \pm 0.002 * \\
(59.86)\end{array}$ \\
\hline & Momordicine & $\begin{array}{c}\text { Control } \\
0.73 \pm 0.02 \\
(100)\end{array}$ & $\begin{array}{c}0.06 \mathrm{mM} \\
0.54 \pm 0.01 * \\
(73.42)\end{array}$ & $\begin{array}{c}0.11 \mathrm{mM} \\
0.51 \pm 0.03 * \\
(70.27)\end{array}$ & $\begin{array}{c}0.15 \mathrm{mM} \\
0.48 \pm 0.007^{*} \\
(66.02)\end{array}$ & $\begin{array}{c}0.19 \mathrm{mM} \\
0.36 \pm 0.004 * \\
(49.31)\end{array}$ \\
\hline \multirow{2}{*}{$\mathrm{ACP}$} & Benzylamine & $\begin{array}{c}\text { Control } \\
35.07 \pm 0.01 \\
(100) \\
\end{array}$ & $\begin{array}{c}0.3 \mathrm{mM} \\
30.08 \pm 0.03 * \\
(85.71)\end{array}$ & $\begin{array}{c}0.5 \mathrm{mM} \\
25.33 \pm 0.04 * \\
(77.22)\end{array}$ & $\begin{array}{c}0.7 \mathrm{mM} \\
18.34 \pm 0.01^{*} \\
(52.29)\end{array}$ & $\begin{array}{c}0.8 \mathrm{mM} \\
15.40 \pm 0.02 * \\
(43.91)\end{array}$ \\
\hline & Momordicine & $\begin{array}{c}\text { Control } \\
35.07 \pm 0.01 \\
(100) \\
\end{array}$ & $\begin{array}{c}0.06 \mathrm{mM} \\
22.36 \pm 0.01 * \\
(63.75)\end{array}$ & $\begin{array}{c}0.11 \mathrm{mM} \\
19.13 \pm 0.01^{*} \\
(54.54)\end{array}$ & $\begin{array}{c}0.15 \mathrm{mM} \\
17.82 \pm 0.04^{*} \\
(50.81)\end{array}$ & $\begin{array}{c}0.19 \mathrm{mM} \\
16.12 \pm 0.01 * \\
(45.96)\end{array}$ \\
\hline \multirow{2}{*}{ ALP } & Benzylamine & $\begin{array}{c}\text { Control } \\
30.71 \pm 0.27 \\
(100)\end{array}$ & $\begin{array}{c}0.3 \mathrm{mM} \\
21.13 \pm 0.03 * \\
(68.80)\end{array}$ & $\begin{array}{c}0.5 \mathrm{mM} \\
18.29 \pm 0.07 * \\
(59.55)\end{array}$ & $\begin{array}{c}0.7 \mathrm{mM} \\
17.54 \pm 0.37 * \\
(57.11)\end{array}$ & $\begin{array}{c}0.8 \mathrm{mM} \\
16.34 \pm 0.04 * \\
(53.20)\end{array}$ \\
\hline & Momordicine & $\begin{array}{c}\text { Control } \\
30.71 \pm 0.27 \\
(100)\end{array}$ & $\begin{array}{c}0.06 \mathrm{mM} \\
24.15 \pm 0.03 * \\
(78.63)\end{array}$ & $\begin{array}{c}0.11 \mathrm{mM} \\
20.37 \pm 0.21 * \\
(66.33)\end{array}$ & $\begin{array}{c}0.15 \mathrm{mM} \\
19.55 \pm 0.16^{*} \\
(63.66)\end{array}$ & $\begin{array}{c}0.19 \mathrm{mM} \\
17.82 \pm 0.22 * \\
(58.02)\end{array}$ \\
\hline
\end{tabular}

Values are mean \pm SE of six replicates. Values in parentheses indicate percent enzyme activity with control taken as $100 \%$. Concentrations (w/v) have been expressed as final concentration in the incubation mixture present in the cuvette. Acetylcholinesterase activity, $\mu \mathrm{mol}$ 'SH' hydrolyzed/min $/ \mathrm{mg}$ protein. Acid phosphatase activity, $\mu \mathrm{mol}$ substrate hydrolyzed/30 min/mg protein. Alkaline phosphatase activity, $\mu \mathrm{mol}$ substrate hydrolyzed/30 min/mg protein. * Significant $(p<0.05)$ when Student's t-test was applied between treated and control groups.

powder compared to other organic solvent extracts indicates that the molluscicidal components in the leaves and fruits are more soluble in ethanol than other organic solvents. Thin layer chromatography studies indicate that benzylamine and momordicine are probably the active components in $M$. oleifera leaf powder and M. charantia lyophilized fruit powder, respectively. HPLC fingerprinting is the best way for chemical characterization ${ }^{33}$. In the present study, similar retention times were recorded for column purified $M$. oleifera leaf extract $(2.59 \mathrm{~min}$ ) and benzylamine $(2.58 \mathrm{~min})$. Benzylamine is identical to the alkaloid moringine ${ }^{4}$. However, there is one major peak at the retention time of 8.42 min which indicates that although benzylamine is the molluscicidal component in $M$. oleifera leaf, there could be some other chemical components in the column-purified fraction that may be responsible for $M$. oleifera leaf molluscicidal activity. Chronic administration of benzylamine in the drinking water improves glucose tolerance, reduces body weight gain and circulating cholesterol in high-fat diet-fed mice ${ }^{14}$. M. oleifera leaf extract has a protective effect against lipid peroxidation ${ }^{7}$. Extract of $M$. oleifera leaf is also reported to have anti-carcinogenic ${ }^{6}$ and anti-bacterial ${ }^{8}$ activity.

The molluscicidal activity of lyophilized fruit powder of $M$. charantia is due to the presence of momordicine, as evidenced from individual toxicity, thin layer chromatography, and is confirmed by the HPLC retention value $(8.4 \mathrm{~min}$; same with that of pure standard compound). Momordicine, a bitter glucoside, is an alkaloid, concentrated in the fruits of $M$. charantia ${ }^{5}$, the extracts of which possess anti-diabetic activity ${ }^{16}$.
A comparison of the molluscicidal activity of column-purified fractions of $M$. oleifera leaf powder and $M$. charantia lyophilized fruit powder with synthetic molluscicides clearly demonstrates that the former are more potent. The $96 \mathrm{~h} \mathrm{LC}_{50}$ value of the column purified fraction of Momordica charantia lyophilized fruit powder $(6.21 \mathrm{ppm})$ against $L$. acuminata is lower than those of synthetic molluscicides-carbaryl (14.40 $\mathrm{ppm})$, phorate $(15.0 \mathrm{ppm})$, formothion $(8.56 \mathrm{ppm})$ and niclosamide $(11.8 \mathrm{ppm})^{14}$. The $96 \mathrm{LC}_{50}$ values of the crude powder of M. oleifera leaf (197.59 ppm) and M. charantia lyophilized fruit (318.29 ppm) against Lymnaea acuminata are lower than the crude powders of Zingiber officinale rhizome (273.80 ppm), Allium cepa bulb (253.27 ppm) ${ }^{31}$, Canna indica root $(359.02 \mathrm{ppm})^{36}$, Cinnamomum tamala leaf powder $(830.90 \mathrm{ppm})^{34}$.

It is evident from the steep slope values that a small increase in the concentration of different treatments causes a marked mortality in snails. A t-ratio value greater than 1.96 indicates that the regression is significant ${ }^{24}$. Values of heterogeneity factor less than 1.0 denote that in the replicate tests of random samples, the concentration response lines would fall within $95 \%$ confidence limits ${ }^{24}$, and thus the model fits the data adequately. The index of significance of potency estimation g-values (less than 0.5 ) indicates that the values of the mean are within the limits at all probability levels $(90,95,99)$ as it is less than 0.5 .

It is clear from the results that in vivo and in vitro exposure to sublethal concentration of benzylamine and momordicine caused a significant inhibition of AChE, ACP and ALP activity in the nervous 

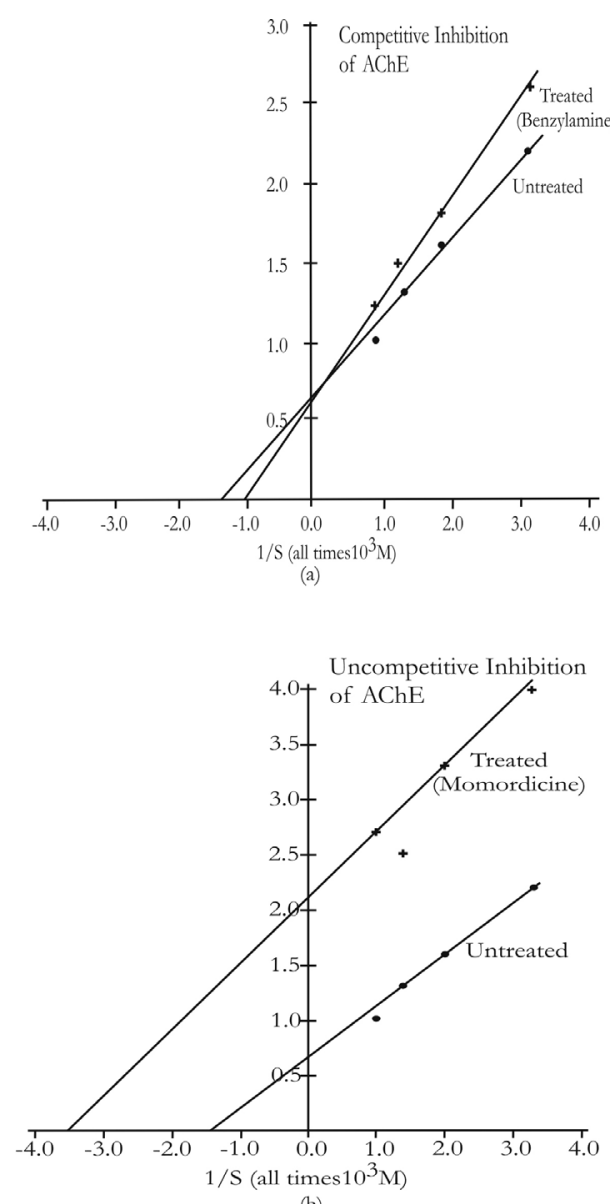

(b)

Fig. 7 - Lineweaver-Burk plots showing the effects of active molluscicidal components benzylamine $(0.7 \mathrm{mM})$ (a) and momordicine $(0.15 \mathrm{mM})$ (b) on the inhibition of acetylcholinesterase (AChE) activity in the nervous tissues of snail Lymnaea acuminata.

tissue of L. acuminata. Inhibition of AChE activity inhibition results in accumulation of acetylcholine at the nerve synapses, such that the postsynaptic membrane is in a state of permanent stimulation, resulting in producing paralysis, ataxia, general lack of coordination in neuromuscular system and eventual death ${ }^{21}$. The methanolic extract of $M$. oleifera leaf significantly inhibited AChE activity at a concentration of $100 \mu \mathrm{g} / \mathrm{mL}^{37}$. Untreated pulp extract of $M$. charantia $\left(\mathrm{IC}_{50^{-}}-7.2 \mathrm{mg} / \mathrm{mL}\right)$ similarly inhibited AChE activity ${ }^{10}$.

Acid phosphatase, a lysosomal enzyme ${ }^{2}$, which plays an important role in catabolism, pathological necrosis, autolysis and phagocytosis ${ }^{1}$, and alkaline phosphatase, which plays a critical role in protein synthesis ${ }^{23}$, shell formation and other secretory activities ${ }^{13}$, transport of metabolites ${ }^{38}$ in gastropods. $M$. oleifera fruit seeds inhibits ACP and ALP activities in arsenic exposed mice ${ }^{11}$, while $M$. charantia fruit extract decreased ALP levels in ammonium chloride-induced hyperammonemic rats ${ }^{35}$.

Results of the kinetic study clearly indicate that inhibition of AChE by benzylamine is competitive as the $\mathrm{K}_{\mathrm{m}}$ values of uninhibited and inhibited enzymes were different while the $\mathrm{V}_{\max }$ were the same (same intercept $\left(1 / \mathrm{V}_{\max }\right)$ on the $\mathrm{Y}$ axis of LineWeaver-Burk plots). Inhibition of $\mathrm{AChE}$ by momordicine is uncompetitive; the slopes of momordicine inhibited and uninhibited $\mathrm{AChE}$

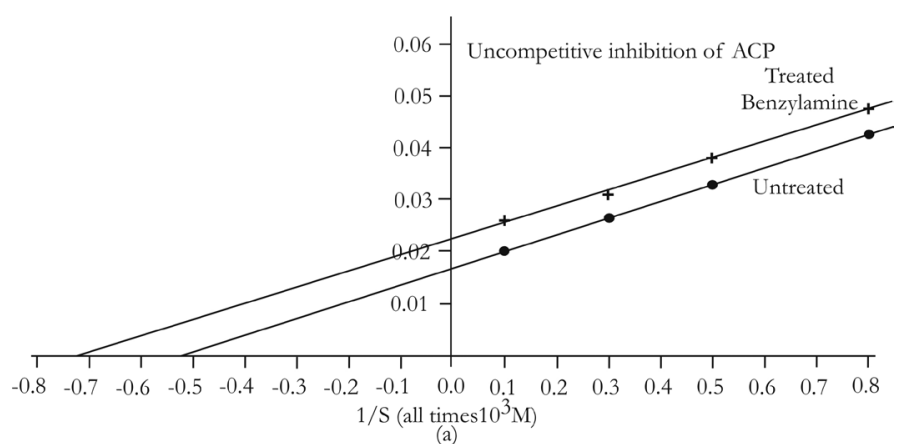

(a)

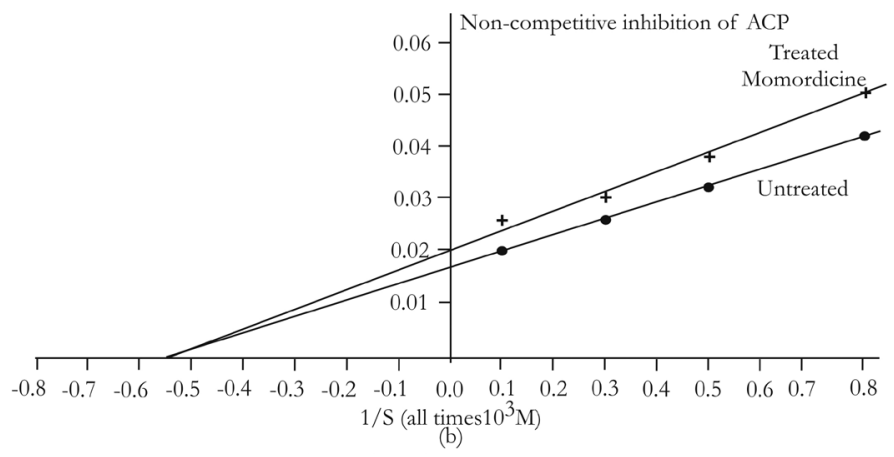

Fig. 8 - Lineweaver-Burk plots showing the effects of active molluscicidal components benzylamine $(0.7 \mathrm{mM})$ (a) and momordicine $(0.15 \mathrm{mM})$ (b) on the inhibition of acid phosphatase (ACP) activity in the nervous tissues of snail Lymnaea acuminata.
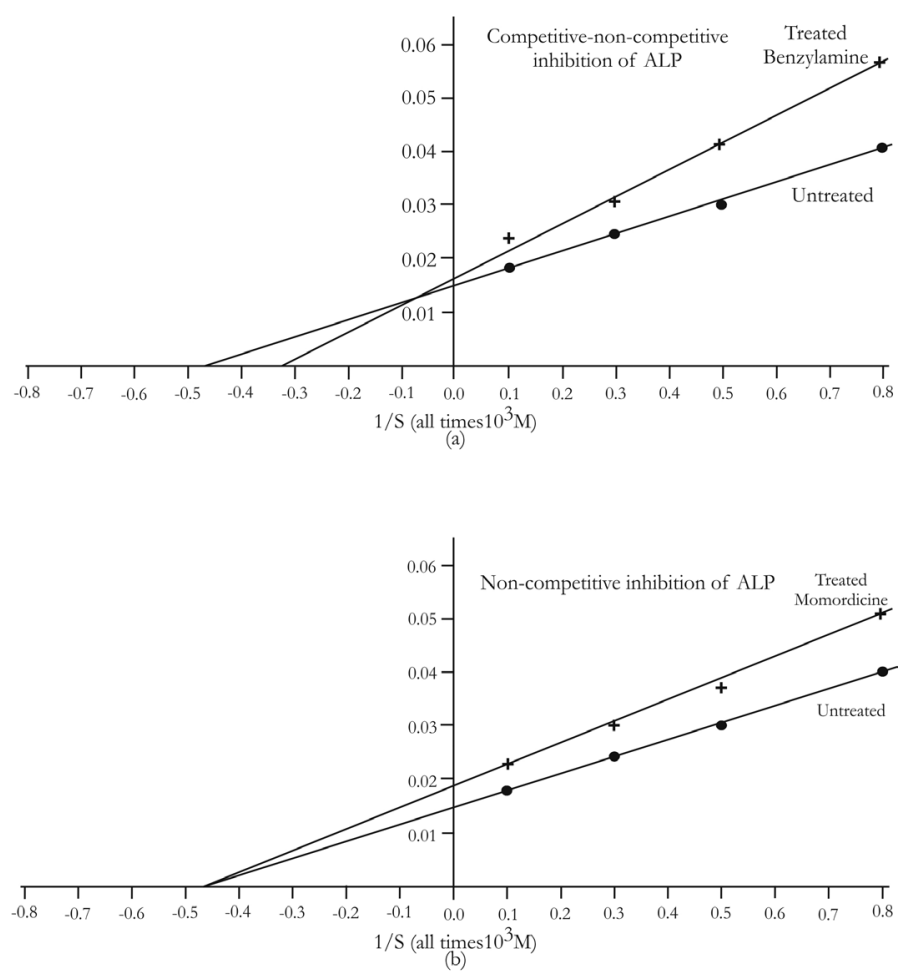

Fig. 9 - Lineweaver-Burk plots showing the effects of active molluscicidal components benzylamine $(0.7 \mathrm{mM})$ (a) and momordicine $(0.15 \mathrm{mM})$ (b) on the inhibition of alkaline phosphatase (ALP) activity in the nervous tissues of snail Lymnaea acuminata. 
UPADHYAY, A.; SINGH, V.K. \& SINGH, D.K. - Characterization of molluscicidal component of Moringa oleifera leaf and Momordica charantia fruits and their modes of action in snail Lymnaea acuminata. Rev. Inst. Med. Trop. Sao Paulo, 55(4): 251-9, 2013.

Table 3

Kinetic constant $\left(\mathrm{K}_{\mathrm{m}}\right.$ and $\left.\mathrm{V}_{\max }\right)$ of different enzyme inhibition by benzylamine $(0.7 \mathrm{mM})$ and momordicine $(0.15 \mathrm{mM})$ in snail Lymnaea acuminata

\begin{tabular}{|c|c|c|c|c|c|c|}
\hline \multirow{2}{*}{ Enzymes } & \multicolumn{2}{|c|}{ Untreated (control) } & \multicolumn{2}{|c|}{ Treated (benzylamine) } & \multicolumn{2}{|c|}{ Treated (momordicine) } \\
\hline & $\mathrm{K}_{\mathrm{m}}$ & $\mathrm{V}_{\max }$ & $\mathrm{K}_{\mathrm{m}}$ & $\mathrm{V}_{\max }$ & $\mathrm{K}_{\mathrm{m}}$ & $\mathrm{V}_{\max }$ \\
\hline $\mathrm{AChE}$ & $7.69 \times 10^{-4}$ & 1.67 & $10 \times 10^{-4}$ & 1.67 & $2.85 \times 10^{-4}$ & 0.48 \\
\hline $\mathrm{ACP}$ & $1.89 \times 10^{-5}$ & 58.82 & $1.40 \times 10^{-5}$ & 45.45 & $1.85 \times 10^{-5}$ & 47.61 \\
\hline ALP & $2.12 \times 10^{-5}$ & 66.67 & $3.22 \times 10^{-5}$ & 62.50 & $2.12 \times 10^{-5}$ & 52.63 \\
\hline
\end{tabular}

Michaelis-Menten constant $\mathrm{K}_{\mathrm{m}}$ and $\mathrm{V}_{\max }$ of different enzymes were calculated from Lineweaver-Burk Plots (1/V versus 1/S)

were parallel to each other, whereas the intercepts were changed. The $\mathrm{K}_{\mathrm{m}}$ and $\mathrm{V}_{\max }$ of uninhibited and inhibited enzymes were different. Inhibition of ALP by benzylamine is competitive non-competitive. It is a mixed type of inhibition. In this case, $\mathrm{K}_{\mathrm{m}}$ and $\mathrm{V}_{\max }$ values of uninhibited and inhibited enzymes were different and slopes were also changed.

Inhibition of ACP and ALP by momordicine is non-competitive, as the $\mathrm{K}_{\mathrm{m}}$ values of uninhibited and inhibited enzymes were the same while their $\mathrm{V}_{\max }$ were different, as evident from different intercepts $\left(1 / \mathrm{V}_{\max }\right)$ on the $\mathrm{Y}$ axis of Lineweaver-Burk plots. Inhibition of ACP by benzylamine is also uncompetitive.

In conclusion, it can be stated that the molluscicidal activity of the leaf powder of $M$. oleifera and lyophilized fruit powder of $M$. charantia is due to benzylamine and momordicine, respectively. Inhibition of $\mathrm{AChE}$, ACP and ALP in the nervous tissue of L. acuminata by benzylamine and momordicine may be responsible for the molluscicidal activity of $M$. oleifera and $M$. charantia. Therefore, purified ethanolic extracts can be used as potent molluscicides as they are easily available, eco-friendly and culturally more acceptable.

\section{RESUMO}

\section{Caracterização do componente moluscicida das folhas da Moringa oleifera e das frutas da Momordica charantia e seus modos de ação sobre o caramujo Lymnaea acuminata}

A atividade moluscicida do pó das folhas de Moringa oleifera e do pó liofilizado das frutas da Momordica charantia contra o caramujo Lymnaea acuminata é dependente do tempo e da sua concentração. $\mathrm{O}$ pó da folha da M. oleifera (96 h $\mathrm{LC}_{50}: 197.59 \mathrm{ppm}$ ) foi mais tóxico do que o pó liofilizado da fruta da $M$. charantia $\left(96 \mathrm{~h} \mathrm{LC}_{50}: 318.29 \mathrm{ppm}\right)$. Os extratos etanólicos do pó de folha da M. oleifera e do pó liofilizado da fruta da $M$. charantia foram mais tóxicos do que outros extratos orgânicos solventes. O $96 \mathrm{~h} \mathrm{LC}_{50}$ da fração purificada por coluna do pó das folhas da $M$. oleifera foi 22.52 ppm enquanto que o pó liofilizado do fruto da M. charantia foi $6.21 \mathrm{ppm}$. Coluna, camada fina e a alta performance da análise da cromatografia líquida mostram que os componentes ativos moluscicidas do pó da folha da $M$. oleifera e do liofiliizado da fruta da M. charantia são a benzilamina ( $\left.96 \mathrm{~h} \mathrm{LC}_{50}: 22.3 \mathrm{ppm}\right)$ e a momordicina (96 h LC $\mathrm{C}_{50}: 1.2 \mathrm{ppm}$ ), respectivamente. A benzilamina e a momordicina inibiram de maneira significante in vivo e in vitro a acetilcolinesterase (AChE), as atividades das fosfatases alcalina e ácida (ACP/ALP) nos tecidos nervosos da L. acuminata. A inibição da atividade da AChE, ACP e ALP nos tecidos nervosos da L. acuminata pela benzilamina e momordicina podem ser responsáveis pela atividade moluscicida da $M$. oleifera e dos frutos da $M$. charantia, respectivamente.

\section{ACKNOWLEDGEMENTS}

One of the authors Aparna Upadhyay is thankful to the Department of Science and Technology, New Delhi for financial assistance (Inspire Fellowship number- IF10296).

\section{REFERENCES}

1. Abou-Donia MB. Increase acid phosphatase activity in hens following an oral dose of leptophos. Toxicol Lett. 1978;2:199-203.

2. Aruna P, Chetty CS, Naidu RC, Swami KS. Acid phosphatase activity in Indian apple snail, Pila globosa (Swainson), during aestivation and starvation stress. Proc Indian Acad Sci. 1979;88:363-5.

3. Bergmeyer UH. Methods of enzymatic analysis. New York: Academic Press; 1967. p. 1129.

4. Bose CK. Possible role of Moringa oleifera Lam. root in epithelial ovarian cancer. Med Gen Med. 2007;9:26.

5. Chaturvedi P, Geoge S, Milinganyo M, Tripathi YB. Effect of Momordica charantia on lipid profile and oral glucose tolerance in diabetic rats. Phytother Res. 2004;18:954-6.

6. Costa-Lotufo LV, Khan MTH, Ather A, Wilke DV, Jimenez PC, Pessoa C, et al. Studies of the anticancer potential of plants used in Bangladeshi folk medicine. J Ethnopharmacol. 2005;99:21-30.

7. Diallo A, Eklu-Gadegkeku K, Mobio T, Moukha S, Agbonon A, Aklikokou K, et al. Protective effect of Moringa oleifera Lam. and Lannea kerstingii extracts against cadmium and ethanol-induced lipid peroxidation. J Pharmacol Toxicol. 2009;4:160-6.

8. Doughari JH, Pukuma MS, De N. Antibacterial effects of Balanites aegyptiaca L. Drel. and Moringa oleifera Lam. on Salmonella typhi. Afr J Biotechnol. 2007;6:2212-5.

9. Ellman GL, Courtney KD, Andres V Jr, Feather-Stone RM. A new and rapid colorimetric determination of acetylcholinesterase activity. Biochem Pharmacol. $1961 ; 7: 88-95$

10. Ghous T, Aziz N, Abid A, Rasheed A, Iqubal M. On-line inhibition study of immobilized acetylcholinesterase by aqueous extracts of Momordica charantia (Bitter melon). J Chem Soc Pak. 2010;32:814-8

11. Gupta R, Dubey DK, Kannan GM, Flora SJ. Concomitant administration of Moringa oleifera seed powder in the remediation of arsenic-induced oxidative stress in mouse. Cell Biol Int. 2007;31:44-56.

12. Hammami H, Hamed N, Ayadi A. Epidemiological studies on Fasciola hepatica in Gafsa oases (South West of Tunisia). Parasite. 2007;14:261-4. 


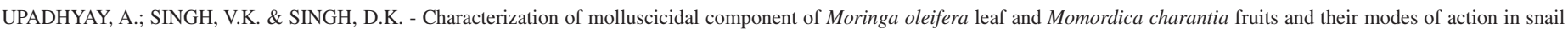
Lymnaea acuminata. Rev. Inst. Med. Trop. Sao Paulo, 55(4): 251-9, 2013.

13. Ibrahim AM, Hegazi MG, Demian ES. Histochemical localization of alkaline phosphatase activity in the alimentary tract of the snail Marisa cornuarietis (L.) Bull Zool Soc Egypt. 1974;26:94-105.

14. Iffiú-Soltész Z, Wanecq E, Lomba A, Portillo MP, Pellati F, Szöko E, et al. Chronic benzylamine administration in the drinking water improves glucose tolerance, reduces body weight gain and circulating cholesterol in high-fat diet-fed mice. Pharmacol Res. 2010;61:355-63.

15. Jaiswal P, Singh DK. Molluscicidal activity of Carica papaya and Areca catech against the freshwater snail Lymnaea acuminata. Vet Parasitol. 2008;152:264-70.

16. Krawinkel MB, Keding GB. Bitter gourd (Momordica charantia): a dietary approach to hyperglycemia. Nutr Rev. 2008;64:331-7.

17. Lowry OH, Rosenbrough NJ, Farr AL, Randall RJ. Protein measurement with folin phenol reagent. J Biol Chem. 1951;193:265-75.

18. Marston A, Hostettmann K. Plant molluscicides. Phytochemistry. 1985;24:639-52.

19. Mas-Coma S, Funatsu IR, Bargues MD. Fasciola hepatica and lymnaeid snails occurring at very high altitude in South America. Parasitology. 2001;123(Suppl):S115-27.

20. Mas-Coma S, Valero MA, Bargues MD. Fasciola, Lymnaeids and human fascioliasis with a global overview on disease transmission, epidemiology, evolutionary genetics, molecular epidemiology and control. In: Rollinson D, Hay SI, editors. Advances in Parasitology. Burlington: Academic Press; 2009. p. 41-146.

21. Matsumura F. Toxicology of insecticides. New York: Plenum Press; 1985. p. 161.

22. Ogundiya MO, Okunade MB, Kolapo AL. Antimicrobial activities of some Nigerian chewing sticks. Ethnobotanical Leaflets. 2006;10:265-71.

23. Pilo B, Asnani MV, Shah RV. Studies on wound healing and repair in pigeon liver. III Histochemical studies on acid and alkaline phosphatase activity during the process. J Anim Morphol Physiol. 1972;19:205-12.

24. Robertson JL, Russell RM, Priesler HK, Savin NE. Bioassay with arthropods. POLO computer programme for analysis of bioassay data. $2^{\text {nd }}$ ed. Boca Raton: CRC Press; 2007. p. $1-224$.

25. Silva TM, Camara CA, Agra MF, de Carvalho MG, Frana MT, Brandoline SV, et al Molluscicidal activity of Solanum species of the Northeast of Brazil on Biomphalaria glabrata. Fitoterapia. 2006;77:449-52.

26. Singh A, Singh DK, Mishra TN, Agarwal RA. Molluscicide of plant origin. Biol Agric Hortic. 1996;13:205-52.
27. Singh DK, Agarwal RA. In vivo and in vitro studies on synergism with anticholinesterase pesticides in the snail Lymnaea acuminata. Arch Environ Contam Toxicol. 1983;12:483-7.

28. Singh DK, Agarwal RA. Inhibition kinetics of certain organophosphorous and carbamate pesticides on acetylcholinesterase from the snail Lymnaea acuminata. Toxicol Lett. 1983;19:313-9.

29. Singh DK, Agarwal RA. Correlation of the anticholinesterase and molluscicidal activity of the latex of Euphorbia royleana on the snail Lymnaea acuminata. J Nat Prod. 1984;47:702-5.

30. Singh DK, Agarwal RA. Toxicity of piperonyl butoxide-carbaryl synergism on the snail Lymnaea acuminata. Int Revue Ges Hydrobiol. 1989;74:689-99.

31. Singh S, Singh VK, Singh DK. Molluscicidal activity of some common spice plants. Biol Agric Hortic. 1997;14:237-49.

32. Sokal RR, Rohlf FJ. Introduction to biostatistics. San Francisco: W.H. Freeman; 1973. p. 171-3.

33. Springfield EP, Eagles PKF, Scott G. Quality assessment of South African herbal medicine by means of HPLC fingerprinting. J Ethnopharmacol. 2005;101:75-83.

34. Srivastava P, Kumar P, Singh DK. Control of harmful snails: Tejpat (Cinnamomum tamala) a potential molluscicide. J Appl Biosci. 2005;31:128-32.

35. Thenmozhi AJ, Subramanian P. Antioxidant potential of Momordica charantia in ammonium chloride-induced hyperammonemic rats. Evid Based Complement Alternat Med. 2011;1-7.

36. Tripathi SM, Singh DK. Molluscicidal activity of Punica granatum bark and Canna indica root. Braz J Med Biol Res. 2000;33:1351-5.

37. Vinutha B, Prashanth D, Salma K, Sreeja SL, Pratiti D, Padmaja R, et al. Screening of selected Indian medicinal plants for acetylcholinesterase inhibitory activity. J. Ethnopharmacol. 2007;109:359-63

38. Vorbrodt A. The role of phosphate in intracellular metabolism. Postepy Hig Med Dosw. 1959;13:200-6.

Received: 14 April 2012

Accepted: 23 October 2012 